SJ Quinney College of Law, University of Utah

Utah Law Digital Commons

$9-2021$

Sexual Assault Enablers, Institutional Complicity, and the Crime of Omission

Amos N. Guiora

Follow this and additional works at: https://dc.law.utah.edu/scholarship

Part of the Criminal Law Commons, and the Law and Society Commons 
Submission to the Victorian Parliament Legislative Council Social and Legal Committee

\section{Sexual Assault Enablers, Institutional Complicity, and the Crime of Omission}

Professor Amos N. Guiora

S.J. Quinney College of Law, University of Utah 


\section{$\underline{\text { TABLE OF CONTENTS }}$}

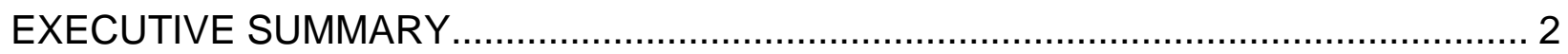

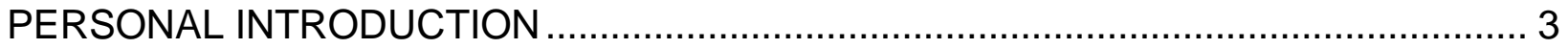

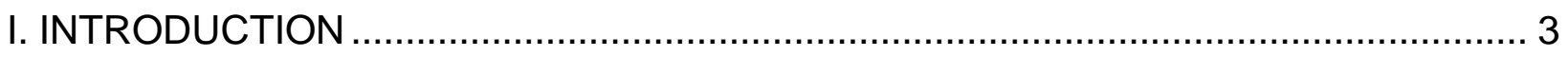

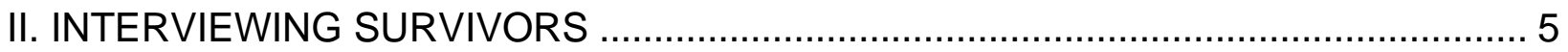

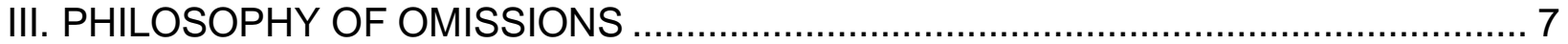

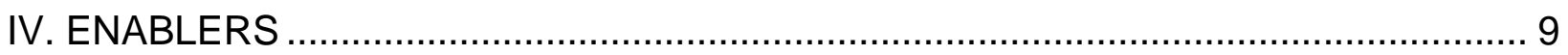

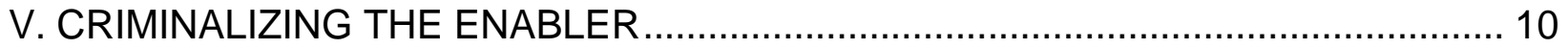

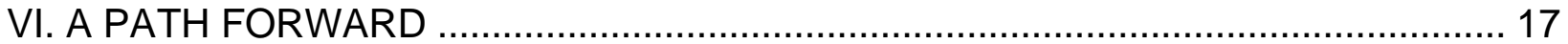


Author's Note: The document was a submission to the Victorian Parliament Legislative Council Social and Legal Committee. I am deeply indebted to Eric Thorne (S.J. Quinney, J.D. expected 2022), Malea Bauer (University of Utah, Honors College, B.A. expected 2023, Joe Stroud, In Good Faith Foundation (Australia); Clare Leaney, In Good Faith Foundation (Australia) and Hannah Aroni, In Good Faith Foundation for the extraordinary teamwork, dedication, and commitment that marked our remarkable collaborative process.

\section{EXECUTIVE SUMMARY}

Sex abuse, particularly of children, is a crime which any rational person would wish to prevent. However, when an individual's loyalties and responsibilities to an institution put them at odds with preventing sex abuse, it is far too often the institution which takes precedence. This is the grim phenomenon of institutional complicity. It is a plague which, sadly, permeates institutions of all types, be it a school, hospital, sports team, church, military, or government agency. It also permeates countries as a global issue.

I have interviewed dozens of survivors who suffered under an abuser who was protected by an institution. The survivor's expectation of the institution is simple: to be protected. Yet, time after time, these survivors found that it was the good name and reputation of the institution which was protected rather than themselves. Many survivors express that their anger towards those who enabled the abuse is greater than their anger towards the abuser.

In this submission I propose that the answer is to criminalize the enabler. By enabler, I mean an individual who knows that sex abuse is occurring and yet fails to inform the appropriate law enforcement agency. I have come to the conclusion that the harm caused by sexual assault enablers does rise to the level of criminality. The harm inflicted by the enabler's deliberate choice to abandon those in their power to protect is a plague which should be addressed by every government.

To that end, I make the following recommendations. I invite this committee to ensure a law exists which does the following:

- Criminalizes those who know sex abuse is occurring but fail to report to law enforcement

- Extends to all persons, regardless of their relationship to the victim

- Ensures that protecting an institution is not a valid defense

- Requires immediate reporting

- Is broad enough to protect anyone vulnerable to sex abuse, be they child or adult

- Applies whenever the abuser presents a continuous threat to future victims

- Provides reasonable exceptions and protections, particularly if the reporter is themselves in danger of abuse

- Is known and understood by law enforcement and prosecutors

- Is known and understood by the public 


\section{PERSONAL INTRODUCTION}

I am a Professor of Law at the S.J. Quinney College of Law, University of Utah. I am the inaugural Chair of the University of Utah Independent Review Committee (Presidential appointment), mandated to review safety and security measures, decisions, and actions by the University's Public Safety Department. I was elected to the University of Utah's Academic Senate Executive Committee.

Relevant to my testimony, my academic writings include The Central Role of Enablers and Bystanders in Athlete Abuse: Applying a Legal Framework to the Culture of Complicity in Sport (co-authored. International Sports Law Journal, forthcoming); Armies of Enablers: Complicity and Betrayal in Sexual Assaults, (American Bar Association, 2020); Failing to Protect the Vulnerable: The Dangers of Institutional Complicity and Enablers (University of Illinois Law Review, forthcoming 2022); The Crime of Complicity: The Bystander in the Holocaust (American Bar Association); Bystander Legislation: He Ain't Heavy, He's My Brother, (co-authored, Kansas Journal Law and Policy, 2020).

I have testified both before the State of Utah House of Representatives regarding criminalizing the bystander and the Dutch National Rapporteur regarding sexual exploitation of children. This past March, Governor Spencer Cox signed Utah H.B. 182 regarding mandatory reporting and the bystander to which my research contributed. Furthermore, I have worked with elected officials in other states regarding the criminalization of bystanders and enablers.

I have spoken at Webinars hosted in the U.K., South Africa, Australia, and the U.S. on issues pertinent to this testimony. In addition, I have been invited to testify as an expert witness regarding institutional complicity, bystanders, and enablers. ${ }^{12}$

\section{INTRODUCTION}

Madam Chair, Members of this Distinguished Committee; it is a great honor to be invited to speak before you today on the topic at hand. I can but hope my submitted testimony sheds light on an issue that has sadly gone unobserved or disregarded for far too long. As I have come to learn, and as explicated below, the power of the enabler and the consequences of their actions demand our urgent attention. While criminalizing omission causes discomfort in many quarters, the time has come for us to put that traditional hesitation aside.

We need to recognize that the decision not to act when there is knowledge of harm to another cannot be tolerated. The harm this causes to the person in peril is significant, sometimes very significant, and sometimes fatal. We are at a crossroads on this issue. As I have come to learn, and as I note below, the omission of the enabler is frankly no less impactful than the commission of the perpetrator. The

\footnotetext{
1 See Appendix A for my full Curriculum Vitae.

${ }^{2}$ You can also view my faculty profile at faculty.utah.edu/u0586620-AMOS GUIORA/hm/index.hml\#.
} 
distinction between commission and omission must not be understood as justifying or overlooking the enabler, as if their decision towards inaction did not cause any harm.

It is for that reason, Madam Chairwoman and Members of this Committee, that I warmly applaud your decision to hold this hearing. It is my fervent hope that this will result in much needed legislation both in Victoria and in other states in Australia. It would be my great honor to participate in a legislative process whereby Australia takes the lead worldwide and is so recognized and acknowledged. The fact that we have allowed the enabler to escape the law has had dire consequences for survivors. They bear the brunt of our collective failure to criminalize the individual who had knowledge and yet chose to do nothing. This hearing, and hopefully pursuant legislation, is a welcome undertaking from the perspective of many survivors. It is their voices that need to guide our discussion.

In that spirit, my testimony will be divided into the following sections: I: Introduction; II: Interviewing Survivors; III: Philosophy of Omissions; IV: Enablers; V: Criminalizing the Enabler; VI: A Path Forward.

Criminal liability has typically been reserved for those who have both actus reus and mens rea. Liability for true omissions is infrequent in modern criminal codes and even less frequently enforced. Despite wide public support for aiding those in peril, Western democracies have historically refused to impose any penalty upon those who fail to aid someone in danger.

However, recent high profile abuse scandals, including those of the USA gymnastics team, University of Michigan and the Catholic Church, have caused scholars and policymakers to rethink these assumptions. In recent years, some jurisdictions have slowly come to criminalize those who witness another in peril and fail to provide aid. Unfortunately, most governments have remained silent on whether to punish actors not present, but who learn of the endangerment of the victim and squander their unique ability to protect them. Indeed, unlike other threats to society, current legislation does not effectively criminalize these enablers of crime.

The enabler is defined as follows: an individual who knows, or should know, that another individual has been harmed and makes the decision to not act to either minimize harm to that individual and/or to other potential victims. The enabler is not present when the harm is caused but fails to act when information regarding the harm is brought to their attention. The enabler has the power to protect the victim, but nevertheless chooses not to act on their behalf. While not physically present when harm occurs, obligation and liability should not be viewed differently because of the knowledge requirement which is an essential element of the definition.

Criminalizing omission, whilst the source of discomfort-legal and legislative-is an essential step in directly addressing abuse. Examining the issue from the perspective of the person in peril provides a path towards more effectively redressing the harms suffered by crime victims. We need to punish enablers who 
protect the perpetrator. Doing so requires recognizing that two crimes often occur simultaneously, almost symbiotically: the actor's crime of commission and the enabler's crime of omission. Until we recognize the power of the crime of omission, survivors will confront perpetrators who are protected by enablers. The time has come to say, "enough is enough."

To that end, my testimony proposes criminalizing omission as an essential tool in that critical effort. It does not focus on the actions of the perpetrator. That I leave to others. Rather, I focus on the actor whose omission enables the perpetrator. That actor is the enabler: the person who knew or should have known of the perpetrators conduct.

\section{INTERVIEWING SURVIVORS}

My perspective on enablers is greatly impacted and shaped by interviews I have conducted with sexual assault survivors. While I am not, under any condition, their spokesman, I do allow myself the privilege of speaking on their behalf regarding the harm enablers caused them. Over the course of the past three years, I have interviewed sexual assault survivors from USA Gymnastics, Michigan State University, The Ohio State University, the Catholic Church, and the University of Michigan. In addition, I have communicated with parents whose children were sexually assaulted and murdered.

I came to learn from survivors that there are direct ramifications emanating from the inaction of enablers. I wish to share with the committee but a few examples:

Mattie Larson was an elite Olympic level gymnast, competing under the auspices of USA Gymnastics. Ms. Larson is a survivor of the horrific crimes of USAG and Michigan State University Doctor Larry Nassar who was convicted in 2017 and sentenced to over 60 years in prison. Ms. Larson was sexually assaulted by Nassar on 750 different occasions. When I asked Ms. Larson what her expectations were of USAG officials, her answer was concise: "to be protected." When I asked Ms. Larson about the consequences of the enablers failure to protect her, the answer was similarly concise: "I was abandoned."

Jade Lewis, a star tennis player at Louisiana State University, was sexually assaulted and brutalized by her boyfriend Drake Davis, at football player also at LSU When Ms. Lewis reported the assault to her coaches, she was rebuffed and dismissed. As these lines are written, LSU has been sued by multiple parties, including Ms. Lewis. An independent report has clearly articulated an enabling culture at LSU that placed vulnerable student athletes at peril.

Lauren McCluskey was a student-athlete at the University of Utah. Ms. McCluskey was murdered in October 2018 on the University campus by a non-student with whom she had had a previous relationship. Prior to the murder, Lauren, her friends, and teammates had shared their deep worries regarding this individual, and the danger he posed, with student housing and campus police officials who did not act on the warnings. In the aftermath of a settlement between the University and Lauren's parents, 
a Foundation has been established to address many of the issues relevant to my testimony (the decision to create an Independent Review Committee-which I Chair as noted above - was one of the "lessons learned" from Lauren's murder).

I respectfully request the Committee recall Ms. Larson, Ms. Lewis, and Ms. McCluskey in the discussion and also note these are but a few examples. Sadly, as I have come to learn, it would be impossible to share all such stories with the Committee as they are endless and continuing.

It is sadly unnecessary to point out that this abuse transcends boundaries. This trauma and victimization of people is universal, which is what brings me before you today. Lest you need convincing of this universality, I offer you another three examples of the crime of omission, all taking place here in Victoria. These examples are offered with the caveat that I have not personally interviewed these survivors.

There has been previous discussion of the scandals within the Catholic Church, not localized to the United States: Cardinal Pell is an example that I am aware hits home here in Victoria. Pell fostered an environment of enabling child molestation here in Melbourne, not unlike his predecessor Frank Little, former Archbishop of Melbourne. When parents approached Little about their children being assaulted by Father Frank Vears (now Russel Walker), he concealed the crime for 30 years. Vears confronted the mother after mass and continued to assault the boy during this time. Little responded by simply relocating him to another parish. Another man under his purview, Father Searson, was known to abuse boys and show them dead bodies. When concerns were made known to Little, he either dismissed the parents or encouraged them to speak directly to Searson. Pell and Little both resonate darkly with my experience working with survivors of Cardinal Law here in the United States. Like his Australian counterparts, Law relocated and "rehabilitated" known offenders rather than protect the innocent child victims.

But just as these crimes are not confined by boundary, neither are they encapsulated by religion. Perhaps a perfect example of this transcendence of these communities is Malka Leifer. Malka Leifer, a former teacher and principal of Melbourne's Adass Israel School in Melbourne, faces 74 counts of sexually abusing children during her position at the school. Leifer, the perpetrator, was enabled by many people, but l'll point to just one enabler: former Deputy of Health Minister of Israel Yaakov Litzman. Leifer, an Israeli-Australian dual citizen, fled to Israel in 2008 after her former students came forward with allegations. Litzman is said to have pressured psychiatrists to proclaim Leifer as mentally unfit to be tried for her crimes. Litzman actively sought to create an environment of protection around Leifer, thus shielding her from the responsibilities of her crimes. He omitted his duty to yield her to due process and justice. Israel will indict Litzman contingent on a hearing.

Finally, the Royal Commission into Institutional Responses to Child Sexual Abuse is a well-known body here in Australia, and many of their 57 case studies point to tragedies in Victoria. The Melbourne Response, Australian Christian Churches, the Yeshiva College in Melbourne, the Royal Children's Hospital in Victoria, Geelong 
Grammar School, and several youth detention centers are all named. In each of these examples, children, and occasionally their parents, were either disbelieved or entirely dismissed. Many children were in fact punished for coming forward with their accusations.

I could continue to provide examples of the crime of omission concerning sexual assault, from any country in the world, but we are not here to pander about the problem. Rather, we are here to formulate a solution to the crime of omission. This is not to say that there were no existing protections in these cases; in some of the examples, duty of care principles were already instituted. This raises another question-not only of how to criminalize the crime of omission - but also how to optimize the existing patchwork of legislation. If people were effectively required to report sexual abuse, then Pell, Little, Litzman, and the subjects of the case studies of the Royal Commission would not be able to perpetuate the cycle of concealing and enabling abuse.

While these stories are important-for hearing survivors is essential-the more pressing challenge facing this distinguished Committee specifically, and society generally, is how to most compellingly and decisively address the scourge of the enabler. Larry Nassar was able to assault Mattie and hundreds of others only because of the decision of the enabler. The same is true in all of the examples listed above. Our challenge is to prevent these stories from being repeated.

\section{PHILOSOPHY OF OMISSIONS}

The crime of omission is not a new concept; it has been recognized for millennia. In one of his writings, the ancient Greek philosopher Plato suggested that prison or banishment was an appropriate punishment for one who witnessed a crime but did nothing to stop it. Likewise, the Roman scholar Cicero once wrote, "He who does not, when he can, ward off or repel wrong is guilty of injustice ... what is to be thought of him who, so far from repelling, abets the wrong?"

It is unclear the full extent to which these suggestions were legislated anciently, but there are some examples of codification. Ancient Roman law punished homicide caused by failure to provide food to another or, for doctors, failure to finish a surgery. Other punishable offenses included the failure of a soldier to protect their superiors and the failure of certain family members to protect each other. Later, under Roman Catholic canon law, St. Thomas Aquinas championed the idea that certain omissions could be a greater sin than some commissions, and even stated, "non-action is a kind of action."

Despite nearly universal support of the morality of those who aid another in harm-religious and otherwise-as European jurisprudence matured, it quickly divorced itself from the idea of punishing omissions. By the eighteenth and nineteenth centuries, most European jurisdictions had distanced themselves from the idea of punishing omissions. 
Nowhere was this more apparent than in England. English common law initially refused to find liability for omissions. This position was ardently defended, even late into the nineteenth century. For example, James Fitzjames Stephen once proposed the following hypothetical: "a number of people who stand round a shallow pond in which a child is drowning, and let it drown without taking the trouble to ascertain the depth of the pond, are, no doubt, shameful cowards, but they can hardly be said to have killed the child."

It was not until the very end of the nineteenth century that English courts began to recognize some exceptions to this baseline rule. One of the first exceptions was finding there to be a duty to act when one had voluntarily assumed the care of another. Critically, that case was one of the first to articulate the oft-repeated assertion that "it would not be correct to say that every moral obligation involves a legal duty; but every legal duty is founded on a moral obligation." The Crown Court subsequently carved out more exceptions, creating a duty to act when one creates a harmful situation or where there was a contractual duty to act. This viewpoint on the crime of omission has been replicated in many Western jurisdictions, including America and Australia.

While crimes of commission are familiar and readily understood, the crime of omission raises significant concerns. The failure to consistently incorporate crimes of omission in criminal codes ensures those who could have acted to protect the person in peril evade legal accountability. But some have argued causation should be the ultimate guidance when it comes to defining which omissions should be criminalized.

The concept and spirit of criminalizing omission is not absent in current Australian law or public support. Just earlier this year, Richard Pusey was sentenced to 10 months in prison for filming the death of four police officers after their injury in a car accident without providing any assistance. Pusey did not create the harm suffered by these officers, but the court recognized and punished the harm his inaction caused.

As favorable a result as that was, it was something of an anomaly. Pusey was charged under outraging public decency. This is already a rare charge and has not been used previously in terms of punishing some forms of omission. In spite of that, this recent development shows that Australian courts are willing to entertain the idea of criminalizing omissions. Moreover, public support for Pusey's sentence has been incredibly strong, with some even frustrated with the length of Pusey's sentence, feeling that it was not long enough. To a certain extent, this situation appears akin to the court bending the interpretation of an existing law to address a public outrage.

Ultimately, the concept of criminalizing omission is not one which should cause concern. In the context of bystander and enabler legislation, the only thing which is lost is the autonomy to refrain from aiding an individual in serious distress. That autonomy does not provide any cognizable benefit to society; indeed, it has caused lifelong agony to untold thousands by protecting those who would turn a blind eye to abuse.

As we turn our attention to the question of consequences, it is incumbent to view the matter exclusively through the lens of the person in peril. 


\section{ENABLERS}

The enabler was not present at the time of peril but knew or should have known and failed to act. Therefore, guilt can be attached to an actor not present when harm occurs but who chooses not to provide assistance to the person in peril. The consequence is that the perpetrator acts knowing those who could prevent the crime will not do so. More egregious than that, the person in peril comes to recognize that protection will not be offered by those positioned to do so. Absent a case where the enabler would be in harm's way, there is no justification that can withstand legislative, prosecutorial, or judicial scrutiny.

Those instances must be understood to be outliers; in the overwhelming majority of cases, harm would not have befallen enablers had they chosen to protect the individual in peril. In those cases, were they able to compellingly demonstrate their position of peril, criminal sanctions should not be imposed. Absent those unique circumstances there is no justification-from the perspective of the person in peril-in tolerating enabler inaction. While the enabler did not directly cause harm to the survivor, their inaction indirectly caused harm; for that reason, omission, like commission, must be criminalized.

With that, we turn our attention to the mechanism for criminalizing the enabler. Failure to aggressively pursue this course ensures the existing lacuna goes unaddressed and that harms caused by predators will repeat themselves.

However, before doing so we must pause and address the question of "carrot or stick?" While I make the argument that criminalizing the enabler is needed both to deter others and to punish the wrongdoer, others say this is a step too far, suggesting education efforts are sufficient in addressing the enabler. That argument is premised on the argument that criminalizing is "over-kill" and imposing a criminal record on an enabler does not reflect the intent or spirit of the criminal law. The argument reflects concern, perhaps justifiable, with unnecessarily "tagging" an individual as a criminal when, so goes the argument, the act is one of omission.

The deterrence-punishment argument is at the core of criminal law jurisprudence and philosophy. The discourse regarding the effectiveness and intent of deterrence and punishment has been discussed widely. The discussion of whether to criminalize the enabler depends on the perspective from which the question is posed. When viewed from the perspective of the person in peril, the answer is obvious. That is the position advocated in my testimony. However, when viewed from the perspective of the enabler specifically, and broader society in general, alarm bells are raised regarding overreach.

The overreach argument suggests a more measured, perhaps moderate approach to the dilemma. Advocates for this approach believe that legislative overreach can have unintended consequences running the gamut from prosecutorial overreach to law enforcement targeting of minority communities to misallocation of government resources to exaggeration of the threat posed by enablers. The suggestion, then, is that the problem is manageable and perhaps not as profound as I propose. Rejection of the 
criminalization proposal, reverting to a "carrot-education" paradigm ultimately fails to do what is most essential: protect the vulnerable.

We should not be dismissive of efforts to educate. However, such efforts, were they to be implemented, must be undertaken in conjunction with implementation of the criminal process. It is "fool's gold" to assume that educational efforts, regardless of their sincerity and desire, can compel enablers to act on behalf of the survivors.

\section{CRIMINALIZING THE ENABLER}

Because our primary motivation is to create a mechanism protecting the vulnerable from perpetrator and enabler alike, we present in this section a road map for criminalizing the enabler. To view harm through the narrow lens of commission, rather than through combination of omission and commission, benefits two actors: the perpetrator (directly) and the enabler (indirectly); the former because they are unencumbered in committing their crime, the latter because they will not be held responsible for their decision.

Some may argue that existing legislation-particularly mandatory reporting laws-are sufficient. There are many reasons why this is incorrect as explained in the following sections. The first two sections are a discussion regarding American law, the second regards Australia, and the final addresses arguments against enabler criminalization generally. While I am, naturally, most familiar with American law, I have-in preparation for my testimony - studied both Australian law and relevant legislative history. There is no intent, under any condition, to suggest the primacy of an American approach; there is, however, value in a comparative approach and analysis. I respectfully request the discussion regarding U.S. law be read in that context.

\section{A. Inadequacies of Mandatory Reporting Legislation}

Every state in the U.S. has adopted some type of "duty to report" or mandatory reporting law. Similar laws have been adopted in Australia, similarly titled "duty of care." These laws generally require an adult in some specified position to report child abuse to law enforcement as soon as they suspect it is occurring. While mandatory reporting laws are undeniably a step in the right direction, they all lack the necessary elements to be truly effective. These elements will be considered in turn:

\section{Who is required to report?}

A few states extend liability for mandatory reporting to all individuals, regardless of position or status. However, a majority of states enumerate those who may be held liable to specific individuals and professions. The former is the preferable approach. Any state which enumerates specific positions to be held liable will obviously fall short of including a certain place where sexual assault occurs. Sexual assault can occur anywhere and by anyone. Nowhere is exempt, and thus, no one should be exempt. Failing to include all persons in a mandatory reporting statute ignores theunfortunate-omnipresence of sexual assault. 


\section{Who is protected?}

Almost every state restricts mandatory reporting protections to the assault of children. Only a handful of outliers require reporting for all victims when rape and/or abuse is suspected, and even then only medical practitioners are required to make such a report. Aside from overlooking the tragic universality of assault and abuse, this also ignores the well-acknowledged effects which sexual assault can have on an individual's ability to protect themselves. While the desire to protect the most vulnerable first is understandable, such a restriction simply provides a window for enablers to disregard abuse of adults. All states should extend reporting protections to all individuals.

\section{When must a report be made?}

Virtually every state requires immediate reporting to a law enforcement agency or abuse hotline. A few states allow a buffer zone of several days before a report must be made. Given the seriousness of abuse and the continuing danger to the victim, immediate reporting is ideal.

\section{What is the degree of criminality?}

Degrees of punishment vary, but failure to comply with mandatory reporting is usually punishable as a class B misdemeanor. This typically entails six months in prison. I find this to be a reasonable minimum punishment, although arguments could certainly be made for harsher penalties.

\section{A refined mandatory reporting statute}

By analyzing all these factors, we can define a "refined" mandatory reporting law as one that 1 ) requires all adults to report; 2) protects all individuals, regardless of age or disability; 3 ) requires immediate reporting; 4 ) punishes failure to report as a misdemeanor requiring at least 6 months in prison. The phrase "we're all mandatory reporters" captures the spirit of these proposed changes. It is no different from the oftrepeated sentiment in torts that we all have a duty to act reasonably to each other, regardless of our differences or conflicts. Survivors deserve no less from a modern, civilized society.

\section{B. Inadequacy of Other Options}

Aside from mandatory reporting, there are many other types of laws which come close to criminalizing enabling behavior yet fall short in one way or another. The purpose in reviewing these forms of legislation is twofold. First, it demonstrates how currently existing legislation, in a way, embraces the idea of criminalizing omission and holding individuals responsible for harms they did not instigate. Second, it demonstrates how criminalization of enablers may simply require a different interpretation of current legislation as opposed to a new law. 


\section{Criminal negligence}

Criminal negligence is described as "a material forsaking of expected concern, vital abandonment of required care, or real divergence of appropriate concern," as well as "aggravated, culpable, gross, or reckless conduct that is such a departure from that of the ordinarily prudent or careful person ... as to be incompatible with a proper regard for human life." It is important to note that "criminal negligence" may refer either to an independent crime or to the mens rea element of the model penal code.

On the surface, this seems to align perfectly with my core argument: criminalize the enablers because their conduct-their omissions-represent a substantial and unjustifiable deviance from the ordinary standard of care each human being owes to each other. Moreover, the crime of negligence is tied to the tort of negligence, which clearly enumerates a general duty of care which all human beings owe each other.

Despite this seemingly good fit, most states interpret their criminal negligence statutes only in terms of commission, especially as related to homicide. In jurisdictions where broad criminal negligence statutes exist, it may be more advisable to expand interpretation of those statues to encompass enabling behavior rather than creating a separate statute.

\section{Reckless endangerment}

In basic terms, reckless endangerment entails causing another to be put in circumstances which may result in death or serious injury. For example, the Utah reckless endangerment statute reads, "a person commits reckless endangerment if, under circumstances not amounting to a felony offense, the person recklessly engages in conduct that creates a substantial risk of death or serious bodily injury to another person." There also exists child endangerment statutes which criminalizes such behavior more severely when harm results to a child, although many of these statutes restrict liability to the parent or guardian of said child.

There is an argument that enabling behavior constitutes reckless endangerment. According to the Model Penal Code, one acts recklessly when one "consciously disregards a substantial and unjustifiable risk that the material element exists or will result from his conduct." It is an easy argument that the behaviors exhibited by many enablers easily falls within this definition.

Yet American courts have interpreted reckless endangerment in terms of commission, not omission. As such, most reckless endangerment statutes envision more overtly malicious acts; for example, deliberately leaving someone alone in a desert and driving away.

\section{Accessory after the fact}

Many jurisdictions criminalize accessories "after the fact." In general terms, this means aiding or otherwise assisting one who has committed a crime, especially when 
helping them to avoid punishment. For example, the U.S. code criminalizes an individual who "receives, relieves, comforts or assists the offender in order to hinder or prevent his apprehension, trial or punishment, is an accessory after the fact." On the surface, this seems to describe enablers who could be said to have assisted those guilty of sexual abuse. Yet again, in application courts have restricted interpretation to actions which involve more overt, physical actions, avoiding any application to crimes of omission.

There is clearly an underlying common thread: the failure to recognize the crime of omission. While new statutes could —and perhaps should — be made, some may find it more prudent to expand the reach of already existing legislation like these crimes so as to encompass omission. Either way, changes must be made in order to fully and effectively criminalize the enabler.

\section{Australia-Specific Statutes}

I do not pretend to be an expert in Australian law. But over the past several weeks, and with the competent help of several friends, I have come to an understanding of some Victorian law addressing this topic. I will refrain from specific legislative recommendations. Rather, I provide general criticisms and suggestions which I would invite this commission to consider when analyzing the effectiveness of these laws.

I found three existing provisions in Victorian law which could be effective in criminalizing the enabler. The first is mandatory reporting. As expansive and helpful as they are, I would posit the same criticisms against them as I did the American mandatory reporting laws outlined above.

The second is criminal negligence. In Victoria, this is understood to mean that, "a person who by negligently doing or omitting to do an act causes serious injury to another person." ${ }^{3}$ As with its American counterparts, the plain language of this statute seems to encompass the idea of punishing the enablers listed above. However, in practice the statute is rarely interpreted as such. Criminalizing the enabler with this statute would likely require some clarification by way of amendment or policies adopted by a prosecuting agency.

The third and most intriguing is a new and unique law which has been adopted in some Australian states, in part as a reaction to the Royal Commission into Institutional Responses to Child Sexual Abuse. In Victoria, this was codified as s327 of the Crimes Act 1958. ${ }^{4}$ The statute has been in effect since 2014.

Put simply, this legislation criminalizes anyone who fails to report to the police when they know that a child under the age of 16 is suffering sexual abuse. Critically, this statute specifically states that protecting the interests, legal or otherwise, of an institution is not a valid excuse. The statute provides immunity to anyone who

\footnotetext{
${ }^{3}$ Crimes Act 1958, (Vic) s.24 (Austl.).

${ }^{4}$ Crimes Act 1958, (Vic) s.327 (Austl.).
} 
reasonably fears that making a report would bring harm to any person, including themselves.

For what it does and who it protects, section 327 does many things right, and rectifies many of the criticisms of mandatory reporting listed above. For one, it extends liability to all adults. This greatly expands the number of people who will be required to provide assistance as opposed to limiting that number to a select few professions. Moreover, this statute is practically designed to attack institutional complicity by explicitly stating that the interests of protecting the child come before the interests of the institution. Finally, the statute keeps in mind situations in which a person may be harmed by making a report by providing immunity to such individuals.

This statute is novel, important, and groundbreaking. If adopted in every country, it could be the vehicle by which institutional complicity is punished and, by way of deterrence, reduced to the point that it ceases to be the noxious plague it is today. The following criticisms of this statute come by way of recommendations for refining some aspects of it.

The first criticism comes by way of the age requirement. Reports on the legislative history of this document suggest that there was some debate regarding the age of who is protected. ${ }^{5}$ Some believed that anyone below the age of 18 should be protected while others thought that all persons of any age should be protected. The legislators ultimately concluded to restrict protection to children below the age of 16 .

I would ask this Commission to seriously consider the reasons behind only protecting individuals under the age of 16 . Age is not the only factor which can make an individual susceptible to sexual assault. Numerous other factors can create circumstances which can reduce or remove an individual's ability to protect themselves.

I would like to briefly relate the story of a survivor with whom I have worked extensively. Jon Vaughn was a student-athlete at the University of Michigan (19881990) where he played on the University's football team. During that time, Vaughn was sexually assaulted-abused-raped over 40 times by Dr. Robert Anderson, the University team doctor. Vaughn, and hundreds of other former University of Michigan studentathletes have filed lawsuits against the University, claiming senior officials knew of Anderson's criminal predatory conduct which stretched over 50 years, yet failed to take action to protect them. It is estimated Anderson committed over 40,000 sexual assaults.

Vaughn was an adult when these assaults occurred. His silence on the matterand that of dozens of other survivors-stemmed not from his age, but his life situation and desire to remain in the good graces of the athletic department which had given him so many opportunities. Vaughn's vulnerability to sexual assault did not suddenly evaporate when he hit a certain age. His vulnerability came from racism and the intense

\footnotetext{
${ }^{5}$ Consultation Paper: Criminal Justice, Royal Commission into Institutional Responses to Child Sexual Abuse, pg. 227-233. www.childabuseroyalcommission.gov.au/sites/default/files/filelist/Consultation\%20Paper\%20-\%20Criminal\%20justice.pdf.
} 
pressures of sports culture. I would implore this commission to remember survivors like Vaughn in considering age restrictions in section 327.

The reports on legislative history also suggest that there was some debate regarding sufficient knowledge of the reporter. The statute itself holds that the reporter just needs "reasonable belief" in order for the statute to trigger. But the legislative history suggests that lawmakers wanted this definition to be both objective and subjective. They held that a reporter may gain the requisite knowledge via information obtained by a third party, but that it still may be a defense that the reporter could not actually understand that abuse was occurring.

This raises several difficult questions. While it may be reasonable to consider if an individual has enough information to "connect the dots," that begs the question of whether someone may improperly raise such a defense to avoid liability. Ultimately, I would recommend that "reasonable belief" either be given a more specific definition or else be lowered to the more expansive standard of reasonable suspicion. Since my focus is on the survivor and protecting the individual in peril, I would recommend an objective standard and oppose the introduction of a subjective standard as doing so creates a window through which many enablers may avoid responsibility.

The legislative history also explains that it was intended that this statute would not require a report to be made if someone 16 or older confided in the reporter about their abuse and specifically stated that they did not wish a report to be made. This reflects a similar statute adopted in New South Wales. ${ }^{6}$ While a survivor's autonomy deserves respect, this provision raises some serious questions when the perpetrator is still at large and still has the opportunity to perpetuate abuse. If the abuser is dead or otherwise incapable of causing future harm, there is a stronger argument that the survivor's autonomy should be respected. But when they are still at large, the survivor's desire to keep things quiet must be weighed against the importance of continuing to protect current and future victims.

I would posit that when put on the scales of justice, the responsibility to protect current and future victims far outweighs the benefit of respecting a survivor's autonomy. In any other situation, I would agree that the survivor's wishes should be honored, but when children may be in peril, all else must be stopped and put aside. To that end, I would recommend editing the statute so as to require a report to be made, regardless of the age of the survivor, when victims may continue to be at risk at the hands of the abuser.

This relates to my final textual criticism, being the ex post facto provision. The first subsection of section 327 explains that a report may only be made if the abuse occurred on or after the first of July 2017. I do not wish to stir controversy regarding ex post facto laws generally, but I would once again ask you to consider the prudence of this provision when the perpetrator is still at large. Example after example shows that an abuser can perpetuate their reign of terror for decades. Four years pales in the face of that time span. As the statute currently stands, an individual would not be required to

${ }^{6}$ Crimes Act 1900 (NSW) s.316 (Austl.). 
report if abuse occurred in 2016, even if the abuser has the same access and opportunity to abuse, and even if victims are still in peril. I would recommend this portion of the statute be rewritten to include offenses occurring before 2017 if the abuser is still in a position to cause future abuse.

Finally, there is the question of enforcement. As of 2020, less than 10 people have been charged under this statute. ${ }^{7}$ This may be due to the fact that this is a newer section of the code or because no clear violations have arisen yet. Regardless, I would recommend that this commission do all in its power to see that prosecutors and the police understand when, how, and why to enforce this statute. It is equally important that the people of Victoria know this statute exists, otherwise the deterrence theory of criminal justice will be of ill effect. It may be wise to create trainings or other appropriate methods of education to ensure that all people know understand that their omissions could land them in prison.

Ultimately, as it stands today, section 327 is a monumental first step in criminalizing the enabler. With some refinements, it can serve as the standard for how sexual assault enabling and institutional complicity can be fairly and aggressively prosecuted in all countries.

\section{Arguments and Counterarguments}

It is only appropriate to examine this proposal with a critical eye. With that in mind, below are listed some of the most common arguments against criminalizing enablers and my response by way of counterargument.

Some argue this legislation is potentially harmful to those suffering from abuse. For example, a wife being abused by her husband may be less likely to report instances of her husband abusing others out of fear of retaliation in the form of more abuse. There is a simple solution to this valid concern: provide immunity to those who are being abused or who are in reasonable fear of abuse by the same abuser. This protection is already a part of the aforementioned section 327 and should be a standard feature of any attempt to enabler criminalization.

In that same vein, there are many, especially in employment situations, who may fear retaliation from the hands of the institution for their actions in preventing abuse. Here, again, a relatively simple solution is to expand and/or reinforce whistleblower protections. While many such laws already exist, legislators ought to ensure they work effectively and ensure that the public knows they are in place. Institutions themselves also ought to create internal policies to ensure their own protections for whistleblowers.

Some argue such legislation will result in discriminatory prosecution practices against minorities. This is indeed a valid and ongoing concern which needs to be addressed on multiple fronts. Prosecution review boards, along with other efforts, can be effective at counteracting this concern.

\footnotetext{
${ }^{7}$ Source is an email from the Crime Statistics Agency in the author's records.
} 
Many express concerns that enabler statues such as these will cause people to become paranoid. The counterargument is that the mens rea requirement for knowledge of sexual assault can be defined in a sufficiently distinct way so as to restrict punishment to instances where abuse is reasonably likely to be occurring.

An additional concern is that this legislation will punish people who fail to report not out of a desire to protect their institution, but simply because they are timid. From the survivor's perspective, there is no discomfort which the enabler could possibly experience which could compare to the years of anxiety, fear, nightmares, stress, and often unending pain which can follow even one instance of sexual abuse, let alone hundreds. Failing to enact legislation criminalizing the enabler ensures perpetrators continue to act with immunity and confidence. The continued insistence that criminalizing omission is "one step too far" ensures abandonment of the survivor. Failing to criminalize omission reflects a willingness, intended or otherwise, to protect the enabler rather than to protect individuals from sexual abuse. Such a conclusion is unacceptable. When put on the proverbial scales of justice, the needs of the victim far outweigh concerns of the enabler.

The persistently repeated argument that such efforts are unnecessary since people will usually do the right thing is debunked in example after example. While often held up as the primary reason to oppose criminalizing enabler omission, it reflects abandonment of the person in peril. More than that, the failure to criminalize omission represents an unwillingness to recognize that omission causes harm. To argue that omission is devoid of ramifications is to ignore the plight of the person directly harmed by a powerful combination of the perpetrator and enabler. The melding of commission and omission has one result: terrible harm to the person in peril who was attacked by the perpetrator and abandoned by the enabler.

\section{A PATH FORWARD}

My testimony proposes a way forward to break down a wall constructed over centuries and reinforced on a regular basis that protects perpetrators. It does not require Superman to break it. However, from the perspective of the person in peril, it must truly seem that the wall which protects those seeking to harm them-directly and indirectly - has become impenetrable. That is most unfortunate, reflecting a deeply ingrained opposition to recognizing that the crime of omission is as consequential as the crime of commission. The consistent voices of opposition to criminalizing the omission of bystanders and enablers reflect an unwillingness to examine the dilemma from the perspective of the person most in need of assistance. This resistance only serves to reinforce the entrenched power of abusers, their institutions, and their enablers.

The power dynamic between institutions and their protectors, and the person in peril is illustrative of an overwhelming power imbalance. If there is something we ought to have collectively learned by now, it is that power imbalances cause extraordinary harm, whether directly or indirectly. Power imbalances cut across many sectors; they cannot be claimed by one group. 
Our failure to legislate the crime of omission ensures continuing harm to those who do not have a voice, impacted by a power imbalance that favors the institutions and ensures that society continues to turn its back on them. The time has come for responsibility to be taken. In the preceding pages, we have provided a road map for how to overcome this historical wrong; the time to act is now before what happened at Michigan State, Penn State, USA Gymnastics, LSU, the University of Michigan, and the Catholic Church is perceived as normal.

Survivors deserve better from society. 